\title{
Estimation of Production Cost of Ready to Cook Milk Based Snack 'MILK CRISP'
}

\author{
Bhujendra Soni*, Geeta Chauhan, S.K. Mendiratta, \\ Subhashis Mohapatra and Anuradha Yadav
}

Division of Livestock Product Technology, Indian Veterinary Research Institute, Izatnagar, Bareilly-243122, Uttar Pradesh, India

*Corresponding author

\section{A B S T R A C T}

\begin{tabular}{|l|}
\hline Ke y w o r d s \\
Milk crisp, Ready- \\
To-Cook Milk- \\
Based Snack \\
(RTCMBS), Skim \\
milk coagulum \\
\hline Article Info \\
\hline $\begin{array}{l}\text { Accepted: } \\
\text { 24 July 2020 } \\
\text { Available Online: } \\
\text { 10 August } 2020\end{array}$ \\
\hline
\end{tabular}

Beside nutritive value and acceptability, cost is very important criterion that determines the marketability of any milk and milk-based products. Therefore, in the present study, the cost of production of Ready to Cook Milk Based Snack (RTCMBS) with incorporation of starchy flours and extenders in comparisons with those of control was calculated. To produce quality products scientifically and hygienically, a mini milk processing plant is necessary for commercialization of RTCMBS 'Milk Crisp'. Efficient costing system must generate information which can help to formulate realistic pricing of products. Cost analysis is also helpful to a business firm in controlling and ascertaining cost of production. Lowest retail price for $1 \mathrm{Kg}$ of selected ready to cook milk-based snacks = Rs $359.36 / \mathrm{kg}$ i.e., each $100 \mathrm{~g}$ packet can be sold at retail price of Rs. 36 . However, margin of profit can be substantially increased by using commercial equipment's for increasing per day production.

\section{Introduction}

Milk is an important agricultural produce of the country. As a single commodity, it has the highest value, even as high as the combined value of paddy and wheat. Milk has enjoyed pride of place among all foods in India, being regarded as "nectar" since the dawn of Indian civilization some 5000 years back. Milk is not a status symbol but it is the symbol of nutrition.

Starches and starch derivatives have a long history of use in snack foods, especially as functional ingredients to help them achieve various textural attributes. They are the main constituents of the extruded snacks and are responsible for most of their structural 
attributes. These snacks are dense in energy but are nutritionally poor and it is possible to add functional quantities of beneficial nutrients to them (Huang, 2000).

A snack should be balanced nutritionally, should provide quick energy, easy to eat and of great taste. One requirement transcends all others and is that, a snack should be perceived as healthy (Pikuda and Ilelaboye, 2009). Snack foods being convenient food items are most suitable for working women, school age children and highly mobile population (Lusas and Rhee, 1987). Snacks have become one of the major groups of the functional food products in diet (Roberts, 2002). It can serve the purpose of healthy food, entertaining and tasty food and ethnic cuisines of consumers (Anon, 1998).

Snacks incorporating Milk can open new avenues for small scale entrepreneurs and women co-operatives. These types of products can be marketed without need of refrigeration and have extended shelf life which may allow limitless marketing opportunities. Further the manufacturing of such products can be scheduled to coincide with availability of raw materials or manufacturing capacity.

In view of the above facts, the present research study was conducted to develop a ready to cook (fry) crisp snack from milk (named as 'Milk crisp') with the objectives to estimate the production cost of 'Milk Crisp'.

\section{Materials and Methods}

\section{Source of raw materials}

\section{Milk}

Milk for pursuing this study was procured from the Dairy Technology Section of Indian Veterinary Research Institute, Izatnagar, Bareilly (U.P.). The milk procured was pasteurized one with combination of cow and buffalo milk as per daily production at dairy farm. Skim milk used in this study was prepared by separating the cream using a hand-driven centrifugal cream separator. The physico-chemical characteristics of the skim milk were analyzed before its use in product processing as mentioned below:

\begin{tabular}{|c|c|c|c|c|c|}
\hline Ph & Fat & SNF & Density & Protein & Lactose \\
\hline $6.67 \pm 0.05$ & $0.63 \pm 0.08$ & $8.09 \pm 0.12$ & $31.3 \pm 2.35$ & $2.95 \pm 0.31$ & $4.48 \pm 0.32$ \\
\hline
\end{tabular}

\section{Ingredients}

Starchy flour I, Starchy flour II and extender A and B (names concealed for patenting), salt, vegetable oil and spices etc were purchased from the local market of Bareilly.

\section{Chemicals}

All chemicals used were of Analytical grade and were obtained from standard firms (Qualigens, Mercks, Hi Media, SRL etc.).

\section{Packaging material}

Low density polyethylene (LDPE) films (250 guage) in natural color were used from the manufacturer, M/s Hitkari Industries Ltd, New Delhi for packaging of the products for conducting storage studies.

\section{Raw material cost}

The major determinant of product cost is raw materials, which determine the profit earned by producer. Raw materials used in the 
processing of 'Milk Crisp' are milk coagulum, starchy flour I and II, extender A and $\mathrm{B}$, table salt and citric acid. The retail prices for these ingredients are relatively stable in our marketing system. However, the cost of these ingredients can be reduced if purchased in bulk quantity from distributor/whole sale agent. The costs of raw ingredients are presented in Table 1 and costs of raw materials required per day for $100 \mathrm{~kg}$ formulation are given in Table 2.

\section{Cost of processing equipment's}

Processing machines are used to perform certain operations with speed and accuracy which may not be possible with manual labour. The approximate cost of processing and other machineries required for making 'Milk Crisp' are as follows in Table 3.

Depreciation rate $=10 \%$ per annum

$=$ Rs.36630/annum

=Rs.122.10/day (300 working days /annum)

These processing equipment's can be potentially utilized in making other milk products simultaneously thereby decreasing the cost of inventory items.

\section{Packaging cost}

Milk Crisp' could be packaged in low density polyethylene bags (LDPE bags). About $2.5 \mathrm{~kg}$ LDPE bags are needed to pack the product prepared from $100 \mathrm{~kg}$ formulation, each containing 50/100 g finished product. $2.5 \mathrm{~kg}$ of printed LDPE bags cost Rs.300/day (Rs. 120/kg). Thus, cost of packaging material is Rs.300/day. Cartons are also required for bulk packing and storage for transportation and distribution.

\section{Labour cost}

Presently the labour cost of skilled person is about Rs.300/day and that of unskilled person is around Rs.165/day. For handling $100 \mathrm{~kg}$ formulation two skilled and three unskilled labours are required per day. The labour cost can be calculated as:

Skilled staff $=300 \times 2=$ Rs.600/day
Unskilled staff $=165 \times 3=$ Rs.495/day
Total labour cost $=$ Rs. $1095 /$ day

\section{Cost of electricity}

The electricity charges have been calculated considering the charges of electricity under industry category (Rs. 5/KWh). Thus, the cost of electricity incurred on processing of $100 \mathrm{~kg}$ formulation can be calculated as shown in Table 4:

Therefore, cost of electricity $=65.2 \times 5$

$$
=\text { Rs.326/day }
$$

\section{Cost of water}

Water is the basic requirement for setting up any food processing industry. The cost of water includes the cost of water pump sets, pipeline fitting and electricity incurred in pumping water. For preparing $1 \mathrm{~kg}$ of 'Milk Crisp' formulation, around 15 litre of water is required. So, for $100 \mathrm{~kg}$ it comes to about 1500 litres of water/day. For pumping 1500 litres water, one motor of 1 Horse Power is to be run for 1.5 hours which will utilise 1.5 units of electricity costing Rs. 7.5/day. So total cost of water/day can be calculated as follows:

Cost of bore well, water storage tanks and 1 pump set $\quad=$ Rs.50, 000/-

Depreciation / year @ 10\%=Rs.5000/i.e. Rs.17/day

Therefore, total cost of water/day = Rs.24.5 *Sourcing potable water from municipal supply is cheaper. 
Table.1 Cost of raw ingredients (per kg)

\begin{tabular}{|l|l|c|}
\hline S. No & Ingredients & Cost $(\mathbf{R s} / \mathbf{k g})$ \\
\hline 1. & Whole milk $(4.5 \%$ fat $)$ & 25 \\
\hline 2. & Skimmed milk coagulum $(0.1 \%$ fat $)$ & 150 \\
\hline 3. & Starchy flour I & 55 \\
\hline 4. & Starchy flour II & 20 \\
\hline 5. & Extender A & 70 \\
\hline 6. & Extender B & 70 \\
\hline 7. & Citric acid & 400 \\
\hline 9. & Table Salt & 11 \\
\hline
\end{tabular}

Table. 2 Costs of raw materials required per day for $100 \mathrm{~kg}$ formulation

\begin{tabular}{|l|c|c|c|c|c|c|}
\hline \multicolumn{1}{|c|}{ Ingredients } & \multicolumn{2}{|c|}{ Control } & \multicolumn{2}{c|}{ Treatment A } & \multicolumn{2}{c|}{ Treatment B } \\
\hline & $\begin{array}{c}\text { Quantity } \\
\text { (kg) }\end{array}$ & $\begin{array}{c}\text { Cost } \\
\text { (Rs) }\end{array}$ & $\begin{array}{c}\text { Quantity } \\
(\mathbf{k g})\end{array}$ & $\begin{array}{l}\text { Cost } \\
\text { (Rs) }\end{array}$ & $\begin{array}{c}\text { Quantity } \\
(\mathbf{k g})\end{array}$ & $\begin{array}{l}\text { Cost } \\
(\mathbf{R s )}\end{array}$ \\
\hline Skimmed milk coagulum $\mathbf{( 0 . 1 \%}$ fat) & 55 & 8250 & 50 & 7500 & 45 & 6750 \\
\hline Starchy flour I & 35 & 1925 & 35 & 1925 & 35 & 1925 \\
\hline Starchy flour II & 10 & 200 & 10 & 200 & 10 & 200 \\
\hline Extender A & - & - & 5 & 350 & - & - \\
\hline Extender B & - & - & - & - & 10 & 700 \\
\hline Total & 100 & $\mathbf{1 0 3 7 5}$ & 100 & $\mathbf{9 9 7 5}$ & 100 & $\mathbf{9 5 7 5}$ \\
\hline
\end{tabular}

Table.3 Cost of processing equipment's to prepare $100 \mathrm{~kg}$ formulation for 'milk crisp'

\begin{tabular}{|l|c|c|c|}
\hline Equipment's & No.of items Required & Rate (Rs./item) & Total (Rs.) \\
\hline Processing equipment's & 1 & 50000 & 50000 \\
\hline Cream separator & 1 & 5000 & 5000 \\
\hline Steam cooker & 1 & 50000 & 50000 \\
\hline Hot air oven/ drier & 1 & 5000 & 5000 \\
\hline Electric grinder/ mixer & 1 & 5000 & 5000 \\
\hline Impulse sealer & 1 & 5500 & 5500 \\
\hline Weighing balances & & & \\
\hline Cooling equipment's & 2 & 20000 & 40000 \\
\hline Refrigerators (500L) & 3 & 30000 & 90000 \\
\hline Split a/c (1.5 ton) & & & \\
\hline Utilities & 1 & 1400 & 2800 \\
\hline Gas burner setup & 2 & 10000 & 10000 \\
\hline Gas cylinder & 1 & -- & 100000 \\
\hline Geyser & -- & & 36000 \\
\hline $\begin{array}{l}\text { Utensils and furnitures } \\
\text { (knives, pressing wooden box, tables etc.) }\end{array}$ & & & 3000 \\
\hline Total & & & \\
\hline
\end{tabular}


Table.4 Electricity charges for industrial processing of 'Milk Crsip'

\begin{tabular}{|l|l|l|}
\hline Equipment & Watts x hr & KWh \\
\hline Cream separator & $1000 \times 1$ & 1.0 \\
\hline Impulse sealer & $100 \times 2$ & 0.2 \\
\hline Refrigerator & $150 \times 2 \times 20$ & 6.0 \\
\hline Hot air oven/ incubator & $150 \times 1 \times 20$ & 3.0 \\
\hline Geyser & $2000 \times 6$ & 12.0 \\
\hline Fans/ weighing balances & $500 \times 10$ & 5.0 \\
\hline Electric grinder/mixer & $1000 \times 2$ & 2.0 \\
\hline Air conditioners & $1500 \times 3 \times 8$ & 36.0 \\
\hline Total units & & 65.2 \\
\hline
\end{tabular}

Table.5 Cost (Rs.) of $100 \mathrm{~kg}$ formulation of RTCMBS/day

\begin{tabular}{|l|l|l|l|}
\hline Particulars & Control & Treatment A & Treatment B \\
\hline Raw material cost & 10375 & 9975 & 9575 \\
\hline Cost of machineries (depreciation cost) & 122.10 & 122.10 & 122.10 \\
\hline Packaging cost & 300 & 300 & 300 \\
\hline Labour cost & 1095 & 1095 & 1095 \\
\hline Cost of electricity & 326 & 326 & 326 \\
\hline Cost of water & 24.50 & 24.50 & 24.50 \\
\hline Rent & 333 & 333 & 333 \\
\hline Maintenance & 150 & 150 & 150 \\
\hline Total Processing expenditure (Rs.) & $\mathbf{1 2 7 2 5 . 6 0}$ & $\mathbf{1 2 3 2 5 . 6 0}$ & $\mathbf{1 1 9 2 5 . 6 0}$ \\
\hline Dealer commission (10\%) & $\mathbf{1 2 7 2 . 5 6}$ & $\mathbf{1 2 3 2 . 5 6}$ & $\mathbf{1 1 9 2 . 5 6}$ \\
\hline Transportation cast (3\%) & 381.77 & 369.77 & 357.77 \\
\hline Marketing cost (13\%) & $\mathbf{1 6 5 4 . 3 3}$ & $\mathbf{1 6 0 2 . 3 3}$ & $\mathbf{1 5 5 0 . 3 3}$ \\
\hline Total expenditure (Rs.) & $\mathbf{1 4 3 7 9 . 9 3}$ & $\mathbf{1 3 9 2 7 . 9 3}$ & $\mathbf{1 3 4 7 5 . 9 3}$ \\
\hline
\end{tabular}

Rent

Renting a building large enough to run a small-scale processing plant with all facilities will cost around Rs.10, 000/ month in semi urban areas. Thus, the cost of rent comes to about Rs.333/day.

\section{Maintenance costs}

These are incurred on materials of daily use like telephone, detergents, soaps, sanitizers, hand wash and solid waste material disposal etc. which can be taken approximately Rs.150/day.

\section{Total processing expenditure}

The sum of all above cost (4.4.1 to 4.4.8) account for total cost for the production. Cost of production of product from $100 \mathrm{~kg}$ formulation per day is shown in Table 5.

\section{Marketing costs}

For marketing a processed milk product, the commission to be paid for wholesalers/agents/dealers and retailers come to about 10\%; the cost of bulk packaging and transportation to around 3\% of retail prices of finished products. Therefore, the total 
marketing cost works out to be $13 \%$ of the retail price of the product.

\section{Gross profit}

A gross profit of $12-15 \%$ is considered the optimum for processed food items, which is produced in a small-scale industry. i.e. average gross profit for producers = Rs. $12 \%$

Profit from $100 \mathrm{Kg}$ of product $=\mathrm{Rs} 1765.90$, 1711.66 and 1657.42/day for control, treatment $\mathrm{A}$ and $\mathrm{B}$ respectively.

\section{Product yield}

The cooking yield was around $35.93 \%$,
$37.72 \%$ and $42.50 \%$, for control, Treatment A and $\mathrm{B}$ respectively. However, a safety margin of $1-2 \%$ is to be considered to compensate for losses that might occur during various steps of processing, packaging and marketing. Thus, a final yield of $35 \%, 37 \%$ and $42 \%$ can be considered practical.

Retail cost of ready-to-cook milk-based snacks

Cost of $1 \mathrm{~kg}$ product $=$
Total expenditure + gross profit

\begin{tabular}{|l|c|c|}
\hline \multicolumn{1}{|c|}{ Formulations } & Calculation & Cost $/ \mathrm{kg}$ \\
\hline Control & $\frac{14379.93+1725.59}{35}$ & $=\mathrm{Rs} .460 .16 / \mathrm{kg}$ \\
\hline Treatment A & $\frac{13927.93+1671.35}{37}$ & $=\mathrm{Rs} .420 .14 / \mathrm{kg}$ \\
\hline Treatment B & $\frac{13475.93+1617.11}{42}$ & $=\mathrm{Rs} .359 .36 / \mathrm{kg}$ \\
\hline
\end{tabular}

In conclusion, therefore, suggested lowest retail price for $1 \mathrm{Kg}$ of ready to cook milkbased snacks $($ treatment B) $=$ Rs $359.36 / \mathrm{kg}$ i.e each $100 \mathrm{~g}$ packet can be sold at retail price of Rs. 36. However, margin of profit can be substantially increased by using commercial equipment's for increasing per day production.

\section{Declaration of interest}

The authors report noconflicts of interest. The authors alone are responsible for the content and writing of the paper.

\section{References}

Anon, 1998. An interview with McCormik on trends in snack food industry. Cereal
Food World, 43: 60-65.

Huang, D.P. 2000. New perspectives on starch and starch derivatives for snack applications. Cereal Food World, 40: 528-533.

Lusas, E.W. and Rhee, K.C. 1987. Extrusion processing as applied to the snack foods and breakfast cereals. Ch. 16. In : Cereals and Legumes in Food Supply (Ed. : Dupont, J. and Osman, E.M). Iowa State University Press, Ames, I.A., pp. 201.

Pikuda, O.O. and Ilelaboye, N.O.A. 2009. Proximate Composition of Street Snacks Purchased from Selected Motor Parks in Lagos. Pak. J. Nutr, 8:16571660.

Roberts, W.A. 2002. A function of health. Prepared Foods, pp. 27-30. 


\section{How to cite this article:}

Bhujendra Soni, Geeta Chauhan, S.K. Mendiratta, Subhashis Mohapatra and Anuradha Yadav. 2020. Estimation of Production Cost of Ready to Cook Milk Based Snack 'MILK CRISP'. Int.J.Curr.Microbiol.App.Sci. 9(08): 3242-3248. doi: https://doi.org/10.20546/ijcmas.2020.908.370 